\title{
Gambaran Sedimen Urine Pada Masyarakat Yang Mengkonsumsi Air Pegunungan Di Kecamatan Kendari Barat Kota Kendari
}

\author{
Ruth Mongan ${ }^{1^{\star}}$, Supiati $^{2}$, Susi Mangiri ${ }^{3}$ \\ 1,2,3 Jurusan Analis Kesehatan Poltekkes kemenkes Kendari \\ JI. AH. Nasution. No. G.14, Anduonohu, Kendari, telp (0401) 392492 \\ ${ }^{*}$ Corresponding author email: ruth.mongan0401@gmail.com
}

\begin{abstract}
Abstrak
Air yang bersih dan sehat merupakan kualifikasi yang sangat diperlukan untuk pemenuhan kebutuhan manusia. Air harus mempunyai persyaratan khusus agar air tersebut tidak menimbulkan penyakit bagi manusia. Air pegunungan yang dikonsumsi masyarakat Kelurahan Sodoha Kota Kendari, pada umumnya memiliki kualitas yang baik, tetapi dapat berubah kualitasnya karena berbagai faktor. Penelitian ini bertujuan untuk mengetahui gambaran sedimen urin pada masyarakat yang mengkonsumsi air pegunungan di Kecamatan Kendari Barat Kota Kendari.

Jenis penelitian adalah deskriptif, dengan menentukan prosentase sedimen urin masyarakat yang mengkonsumsi air pegunungan melalui pemeriksaan laboratorium. Jumlah sampel dalam penelitian ini adalah 30 Kepala Keluarga yang tinggal di Kelurahan Sodohoa Kecamatan Kendari Barat Kota Kendari, dengan teknik pengambilan simple random sampling (sampel acak secara sederhana). Berdasarkan hasil penelitian, ditemukan prosentase sedimen urin abnormal, yaitu leuokosit dan eritrosit $6,7 \%$, epitel $23,3 \%$, silinder, kalsium oksalat, asam urat, dan bakteri masing-masing 3, $3 \%$. Kesimpulan dari penelitian menunjukkan adanya sedimen organik yang meliputi, leukosit, eritrosit, silinder, epitel dan bakteri pada masyarakat yang mengkonsumsi air pegunungan Kelurahan Sodohoa Kecamatan Kendari Barat Kota Kendari.
\end{abstract}

Keywords: Air pegunungan, Sedimen, Sodohoa, Urin.

(C) 2017 Jurnal Teknologi Laboratorium

\section{Pendahuluan}

Air merupakan kebutuhan penting bagi makhluk hidup di muka bumi, terutama bagi manusia. Air berperan dalam segala bidang yaitu pertanian, industri, dan pemenuhan kebutuhan rumah tangga, sehingga air yang digunakan harus memenuhi standar ataupun syarat dari segi kualitas maupun kuantitas. Air yang bersih dan sehat merupakan kualifikasi yang sangat diperlukan untuk pemenuhan kebutuhan tersebut. Air minum harus bersih dan jernih, tidak berwarna dan tidak berbau, dan tidak mengandung bahan tersuspensi atau kekeruhan.[1]

Air harus mempunyai persyaratan khusus agar air tersebut tidak menimbulkan penyakit bagi manusia. Menurut Permenkes Nomor 92/Menkes/Per/IV/2010 tentang persyaratan kualitas air Minum, air minum aman bagi kesehatan apabila memenuhi 


\section{JURNAL TEKNOLOGI LABORATORIUM}

(www.teknolabjournal.com)

Vol.6, No.1, Maret 2017, pp. $18 \sim 24$

ISSN: 2338 - 5634 (print); ISSN: 2580-0191 (online)

Received : 27-02-2017; Revised : 21-03-2017; Accepted : 25-04-2017

persyaratan fisika, mikrobiologis, kimiawi dan radioaktif yang dimuat dalam parameter wajib dan parameter tambahan.[2] Penyakit-penyakit yang menyerang manusia dapat ditularkan dan disebarkan melalui air. Penyakit-penyakit tersebut merupakan akibat semakin tingginya kadar pencemar yang memasuki air.[3]

Keterbatasan penyediaan air bersih yang memenuhi syarat memerlukan adanya teknologi tepat guna untuk pengolahanya yang disesuaikan dengan keadaan lingkungan. Untuk memperoleh air bersih minimal diperlukan suatu proses pengolahan standar dengan kapasitas produksi yang sangat besar, agar dapat dinikmati oleh masyarakat.[4] Menurut Sandra [5] air minum merupakan air yang dapat diminum langsung tanpa dimasak terlebih dahulu. Sedangkan air bersih merupakan air yang digunakan keperluan sehari-hari, memenuhi syarat kesehatan dan dapat diminum setelah dimasak terlebih dahulu.

Air minum yang ideal harus jernih, tidak berwarna, tidak berasa, tidak berbau dan tidak mengandung kuman patogen. Air seharusnya tidak korosif, tidak meninggalkan endapan pada seluruh jaringan distribusinya.[6] Komposisi mineral dalam air minum yang bersumber dari air permukaan (dataran tinggi/rendah) didominasi oleh unsur kalsium dan magnesium, kadar kalsium $\left(\mathrm{Ca}^{2+}\right)$. Hal inilah yang harus diwaspadai karena diduga dapat mengakibatkan hipereksresi kalsium urin dan supersaturasi (kristalisasi kalsium oksalat) yang merupakan proses awal terjadinya batu saluran kemih.[7]

Air pegunungan pada umumnya memiliki kualitas yang baik, mengandung mineral-mineral yang sesuai dengan kebutuhan kesehatan dan tidak mengandung unsur-unsur pencemaran yang dapat mengganggu kesehatan. Batuan akuifer pegunungan pada umumnya disusun oleh mineral- mineral yang memberikan unsurunsur kimia air tanah yang diperlukan oleh manusia. Sumber air pegunungan juga biasanya jauh dari sumber pencemaran.

Diantara penduduk masyarakat di Kota Kendari yang mengkonsumsi air pegunungan salah satunya adalah masyarakat yang bermukim di daerah Kecamatan Kendari Barat Kota Kendari. Air pegunungan yang dikonsumsi merupakan air yang dihasilkan dari penampungan mata air. Masyarakat banyak memanfaatkan air pegunungan ini karena harganya murah dan olahannya sangat mudah.

Air pegunungan walaupun banyak dikonsumsi penduduk, dapat menurun kualitasnya. Kepadatan penduduk, dan tata ruang yang salah, dapat berakibat menurunnya kualitas air pegunungan. Penggunaan air pegunungan yang tidak memenuhi syarat kesehatan dapat membahayakan organ tubuh karena adanya senyawa kimia dalam air minum yang melebihi ambang batas konsentrasi. Selain itu dapat menimbulkan penyakit gangguan fungsi organ tubuh seperti fungsi ginjal, hati otak, bahkan kelainan mental. Senyawa kimia ini bisa secara alamiah maupun akibat kegiatan manusia mencemari air minum. Beberapa zat kimia yang bersifat membahayakan terhadap tubuh manusia adalah zat kapur, logam berat, pestisida, senyawa polutan hidrokarbon, zat-zat radio aktif alami atau buatan.[8] Beberapa zat kristal dalam urin yang bersifat abnormal terhadap tubuh manusia adalah kalsium oksalat, triple fosfat, cilinder dan sebagainya.[9]

Kandungan kimia yang terdapat dalam air dapat berbeda menurut jenis sumber airnya. Penelitian yang dilakukan oleh R. Yunus \& T. Yuniarti [10] menemukan adanya perbedaan kristal urin pada orang yang mengkonsumsi air kemasan isi ulang dan orang yang meminum air minum dari sumur gali. Hal ini menunjukkan adanya kemungkinan 


\section{JURNAL TEKNOLOGI LABORATORIUM}

(www.teknolabjournal.com)

Vol.6, No.1, Maret 2017, pp. $18 \sim 24$

ISSN: 2338 - 5634 (print); ISSN: 2580-0191 (online)

Received : 27-02-2017; Revised : 21-03-2017 ; Accepted : 25-04-2017

perbedaan kandungan kimia pada air menurut sumber airnya. Berdasarkan hal tersebut, maka penulis tertarik untuk melakukan penelitian mengenai Gambaran sedimen urin pada masyarakat yang mengkonsumsi air pegunungan di Kecamatan Kendari Barat Kota Kendari”.

\section{Metode Penelitian}

Jenis penelitian adalah deskriptif. Penelitian ini bertujuan untuk menentukan prosentase sedimen urin masyarakat yang mengkonsumsi air pegunungan di Kecamatan kendari Barat Kota Kendari. Pemeriksaan dengan uji laboratorium dilakukan untuk melihat prosentase sedimen urin yang terdapat dalam urin masyarakat yang mengkonsumsi air pegunungan di Kendari barat.

Populasi dalam penelitian ini penduduk di kelurahan Sodoha kecamatan kendari barat, berjenis kelamin laki-laki dan perempuan. Teknik pengambilan sampel menggunakan metode purposive sampling dengan pertimbangan mereka yang bersedia berpartisipasi dalam pemeriksaan sedimen urin, dengan kriteria inklusi: penduduk laki-laki dan perempuan, dan ada di lokasi saat dilakukan pemeriksaan. Sampel.[11]

\section{Hasil dan Pembahasan}

Pada Penelitian ini dapat dilihat data distribusi responden menurut Jenis kelamin dan umur pada tabel 1 dan tabel 2.

Tabel 1. Distribusi Sampel Penelitian Menurut Jenis Kelamin

\begin{tabular}{cccc}
\hline No & Jenis Kelamin & Jumlah & $\begin{array}{c}\text { Persentase } \\
\%\end{array}$ \\
\hline 1 & Perempuan & 27 & 90 \\
2 & Laki-laki & 3 & 10 \\
\hline Total & & 30 & 100 \\
\hline Sumber: & & &
\end{tabular}

Dari data distribusi tabel 1 di atas menunjukkan bahwa dari 30 responden yang menjadi sampel penelitian, terdapat 27 responden $(90 \%)$ berjenis kelamin Perempuan, dan 3 responden (10\%) berjenis kelamin Laki-Laki.

Tabel 2 Distribusi sampel penelitian menurut Umur

\begin{tabular}{rccc}
\hline No & Umur (tahun) & Jumlah & Persentase (\%) \\
\hline 1 & $6-12$ & 1 & 3,3 \\
2 & $13-19$ & 3 & 10,0 \\
3 & $20-26$ & 15 & 50,0 \\
4 & $27-32$ & 5 & 16,7 \\
5 & $33-39$ & 1 & 3,3 \\
6 & $40-46$ & 1 & 3,3 \\
7 & $47-53$ & 3 & 10,0 \\
8 & $54-60$ & 0 & 0 \\
9 & $61-67$ & 1 & 3,3 \\
\hline \multicolumn{4}{r}{} \\
\hline
\end{tabular}

Gambaran Sedimen Urin Pada Masyarakat Yang Mengkonsumsi Air Pegunungan 


\section{JURNAL TEKNOLOGI LABORATORIUM}

(www.teknolabjournal.com)

Vol.6, No.1, Maret 2017, pp. $18 \sim 24$

ISSN: 2338 - 5634 (print); ISSN: 2580-0191 (online)

Received : 27-02-2017; Revised : 21-03-2017 ; Accepted : 25-04-2017

Sumber : Data Primer

Dari data tabel 2 menunjukkan data distribusi sampel umur pada masyarakat yang mengkonsumsi air pegunungan di Kelurahan Sodoha Kecamatan Kendari Barat, dimana responden dengan kelompok umur 20-26 tahun merupakan kelompok responden yang terbanyak $(50,0 \%)$ orang.

Tabel 3. Hasil Pemeriksaan sedimen urine

\begin{tabular}{lllccc}
\hline No & Sedimen Urine & \multicolumn{2}{c}{ Normal } & \multicolumn{3}{c}{ Abnormal } \\
\cline { 3 - 6 } & & $\mathrm{N}$ & $\%$ & $\mathrm{~N}$ & $\%$ \\
\hline 1 & Leukosit & 28 & 93,3 & 2 & 6,7 \\
2 & Eritrosit & 28 & 93,3 & 2 & 6,7 \\
3 & Epitel & 17 & 56,6 & 7 & 23,3 \\
4 & Silinder & 29 & 96,7 & 1 & 3,3 \\
5 & Kalsium oksalat & 29 & 96,7 & 1 & 3,3 \\
6 & Asam urat & 29 & 96,7 & 1 & 3,3 \\
7 & Sistin & 30 & 100 & 0 & 0 \\
8 & Bakteri & 29 & 96,7 & 1 & 3,3 \\
\hline
\end{tabular}

Sumber: Data Primer

Data tabel 3 menunjukkan sedimen urine pada masyarakat yang mengkonsumsi Air pegunungan di Kelurahan Sodoha, Kecamatan Kendari barat. Tabel tersebut menunjukkan jumlah Leukosit normal 28 (93,3\%) dan abnormal 2 (6,7\%), jumlah Eritrosit normal 28 (93,3\%) abnormal 2 (93,3\%). Jumlah Epitel normal 17 (56,6\%) abnormal 7 (23,3\%), Silinder normal $29(96,7)$ abnormal 1 (3,3), Jumlah Calsium Oxalat normal $29(96,7)$ abnormal 1 (3,3\%), jumlah Asam urat normal $29(96,7 \%)$ abnormal $1(3,3 \%)$, jumlah sistin normal 30 (100\%), jumlah bakteri normal $29(96,7 \%)$ abnormal $1(3,3 \%)$.

Pemeriksaan sedimen urine atau mikroskopik pada urine merupakan pemeriksaan lanjutan setelah pemeriksan kimia urine, yang penting untuk mengetahui adanya kelainan pada ginjal dan saluran kemih serta berat ringannya penyakit. Pemeriksaan sedimen ini biasa menggunakan urine pagi ataui urine sewaktu, setelah mengumpulkan urine segera di lakukan pemeriksaan. Untuk penundaan pemeriksaan urine sebaiknya diberikan pengawet karena akan terjadi perubahan pada komposisi zat dan hasil yang di keluarkan seperti terjadinya pertumbuhan bakteri, kadar glukosa menurun, $\mathrm{pH}$ menjadi alkalis, dekomposisi silinder, lisisnya eritrosit, perubahan bentuk leukosit/rusak, urine menjadi makin keruh, perubahan warna dan bau, serta nitrit menjadi positif.[12]

Pada pemeriksaan sedimen urine masyarakat yang mengkonsumsi air pegunungan di Kelurahan Sodohoa, Kecamatan Kendari Barat Kota Kendari di dapatkan variasi gambaran sedimen, dimana hal ini merupakan indikasi kesehatan dan zat-zat yang di konsumsi dalam kehidupan sehari- hari. Pengamatan sedimen tergantung apa yang ada dalam urine normal, dan bisa di identifikasi secara akurat dalam membandingkan antara bentuk normal dan abnormal. Munculnya beberapa partikel atau elemen dalam urine mungkin normal, Hal ini dapat berupa sel-sel 


\section{JURNAL TEKNOLOGI LABORATORIUM}

(www.teknolabjournal.com)

Vol.6, No.1, Maret 2017, pp. $18 \sim 24$

ISSN: 2338 - 5634 (print); ISSN: 2580-0191 (online)

Received : 27-02-2017; Revised : 21-03-2017 ; Accepted : 25-04-2017

darah, sel-sel yang melapisi saluran kencing (epitel squamous), partikel protein silinder yang telah terbentuk di nefron (gips), Kristal yang terbentuk dalam urine, dan sel asing misalnya spermatozoa, mikroorganisme, atau kontaminan.[13]

Eritrosit pada sedimen urine normal dengan jumlah 0-5 sel/LPB dapat ditemukan. Jumlah lebih dari 5/LPB harus di selidiki secara menyeluruh dan penyebab hematuria harus dicari. Dalam pemeriksaan mikroskopik eritrosit terlihat mirip dengan yang di temukan pada darah perifer. Dalam urine hipertonik, eritrosit bisa crenated dan dalam urine hipotonik eritrosit bisa bengkak, menjadi bola, dan waktunya akan pecah, sehinnga jumlah eritrosit berkurang pada sedimen urine.

Leukosit sering di temukan pada sedimen urine normal, tetapi sedikit dan tidak melebihi 5/LPB. Walaupun semua jenis leukosit yang muncul dalam darah perifer juga di temukan dalam urine (yaitu limfosit, monosit, eosinofil), namun sel yang paling umum adalah PMN. PMN memiliki fungsi fagositosis motil secara aktif, dan bergerak secara amuboid dengan pseudopodia. PMN dalam urine dapat segera di ketahui inti multi segmennya dan sitoplasma granular.[13]

Sel epitel urine normal berisi tiga varietas utama sel epitel: tubular ginjal, transisi (urothelial), dan squamos. Sel- sel ini melapisi saluran kemih, tubulus dan nefron. Sel epitel renal tubular jarang ada dalam sedimen urine yang normal (01/LPB). Bila ada, biasanya dalam bentuk tunggal tetapi juga di temukan berpasangan. Sel transisi merupakan lapisan epitel pada sebagian besar saluran kemih dan sering tampak di sedimen (0-1/LPB). Bentuknya bertingkat-tingkat dan biasanya dengan lapisan sel tebal dengan tiga bentuk utama yaitu bulat, polyhedral, dan kecebong. Sel epitel squamos adalah yang termudah dari semua sel epitel, dan mudah di kenali dan sering di jumpai dalam urine karena bentuknya yang besar dan datar, Spesimen urine porsi tengah paling baik di gunakan.[13]

Silinder terbentuk dari kumpulan zat- zat atau sel-sel yang terbentuk padat memanjang dengan ujung bulat. Adanya silinder dalam urine mengindikasikan gejala kerusakan ginjal baik akut maupun kronis. Tidak ada tipe silinder tertentu bagi gangguan penyakit ginjal yang khusus, walaupun terdapat silinder eritrosit dan silinder leukosit.[14]

Kristal terbentuk berkaitan dengan konsentrasi berbagai garam di urine yang berhubungan dengan metabolisme makanan pasien dan asupan cairan serta dampak dari perubahan yang terjadi dalam urine setelah koleksi sampel (yaitu perubahan $\mathrm{pH}$ dan suhu yang mengubah kelarutan garam dalam urine dan menghasilkan pembentukan kristal). Kristal kalsium oksalat paling sering ditemukan pada urine asam dan netral. Bentuk yang umum adalah bentuk dihidrat, Kristal berwarna mirip bentuk amplop. Kristal jenis ini di temukan dalam urine normal, yaitu terutama setelah mengkonsumsi asam askorbat dalam dosis besar atau makanan yang kaya akan asam oksalat.[15]

Kristal asam urat ada di urine dalam konsentrasi yang tinggi dan umumnya menghasilkan berbagai macam struktur kristal, kristal asam urat ada dalam berbagai bentuk seperti batang, kubus, piring, dan seperti batu asahan. Kristal asam urat larut dalam larutan alkalis dan tidak larut dalam asam. Biasanya berwarna kuning pucat, kristal asam urat sering di kaitkan dengan batu ginjal, tetapi keberadaanya di urine orang normal adalah sanngat umum.[15]

Sistin jarang di jumpai (tidak umum), berwarna kuning jeruk dan berkilau. Sedangkan kristal sistin di urine tampak seperti plat segi enam, sangat sukar larut dalam air. Bersifat radioopak karena mengandung sulfur, kristal sistin berasal dari 


\section{JURNAL TEKNOLOGI LABORATORIUM}

(www.teknolabjournal.com)

Vol.6, No.1, Maret 2017, pp. $18 \sim 24$

ISSN: 2338 - 5634 (print); ISSN: 2580-0191 (online)

Received : 27-02-2017; Revised : 21-03-2017 ; Accepted : 25-04-2017

zat yang seharusnya tidak ada dalam urine,maka dapat mengindikasikan masalah metabolisme. Obat-obatan dan pewarna kontras sinar-x- juga dapat mengkristal di dalam urine.[16]

Urine seharusnya steril sehingga tidak akan ada mikroorganisme di urine yang mengindikasikan adanya infeksi. Bakteri dapat memasuki saluran kemih melalui uretra dan naik ke kandung kemih seperti dalam penggunaan air yang terkontaminasi. Bakteri yang terdapat dalam sedimen urine juga dapat merupakan kontaminan, terutama pada wanita, atau wadah sampel yang tidak steril.[13]

Untuk memaksimalkan pada pembacaan sedimen urine hendaknya alat yang digunakan harus dalam keadaan baik seperti kaca objek dan mikroskop. Kaca objek yang kotor tidak bisa di gunakan untuk pembacaan sedimen urine dikarenakan adanya kotoran atau jamur yang menyerupai sel darah. Mikroskop merupakan alat yang utama dalam penelitian sedimen urine ini. Mikroskop yang digunakan harus dengan lensa yang bersih bebas dari debu maupun jamur karena dapat mempengaruhi lapangan pandang pada saat pemeriksaan sedimen urine di bawah mikroskop.[15]

Hasil penelitian menunjukkan sedimen urine pada masyarakat yang mengkonsumsi air pegunungan di Kelurahan Sodohoa Kecamatan Kendari Barat jumlah Leukosit normal 28 (93,3\%) dan abnormal 2 (6,7\%), jumlah Eritrosit normal $28(93,3 \%)$ abnormal $2(93,3 \%)$. Jumlah Epitel normal $17(56,6 \%)$ abnormal 7 $(23,3 \%)$, Silinder normal $29(96,7)$ abnormal $1(3,3)$, Jumlah kalsium oksalat normal 29 $(96,7)$ abnormal $1(3,3 \%)$, jumlah Asam urat normal $29(96,7 \%)$ abnormal $1(3,3 \%)$, jumlah sistin normal 30 (100\%), jumlah bakteri normal $29(96,7 \%)$ abnormal 1 $(3,3 \%)$.

Pada penelitian ini didapatkan responden yang urinnya mengandung kalsium oksalat sebanyak 3,3 \%. Air minum yang mengandung kalsium berhubungan dengan kondisi geografis.[17] Didaerah yang airnya mengandung kapur, insiden penderita batu saluran kencing relatif tinggi. Keterbatasan penelitian adalah tidak dilakukannya observasi mengenai responden yang menderita infeksi saluran kencing.

Penelitian ini relevan dengan penelitian yang di lakukan oleh Obiet [18] yang meneliti perbedaan sedimen urine pada masyarakat yang mengkonsumsi air pegunungan RRI Lama dan Jalan Lasolo, dimana temukan adanya sedimen urin yang abnormal pada masyarakat yang mengkonsumsi air pegunungan.

\section{Kesimpulan dan Saran}

Hasil penelitian menunjukkan adanya gambaran sedimen organik pada urin masyarakat yang mengkonsumsi air pegunungan di Kecamatan Kendari Barat, Kota kendari, yang meliputi: leukosit, eritrosit, silinder, epitel, dan bakteri.

\section{Daftar Pustaka}

[1] U. Suriawiria, Mikrobiologi Air dan Dasar-dasar Pengolahan Buangan Secara Biologis. Bandung: Penerbit Alumni, 2008.

[2] P. M. K. N. 492/menkes/PER/IV/2010 tentang P. kualitas air Minum, "No Title."

[3] K. . Buckle, E. R.A, Fleet, and W. M, IImu Pangan. Jakarta: UI Press, 2009.

[4] C. Sutrisno and Totok, Teknologi Penyediaan Air Bersih. 2004. 


\section{JURNAL TEKNOLOGI LABORATORIUM}

(www.teknolabjournal.com)

Vol.6, No.1, Maret 2017, pp. $18 \sim 24$

ISSN: 2338 - 5634 (print); ISSN: 2580-0191 (online)

Received : 27-02-2017; Revised : 21-03-2017 ; Accepted : 25-04-2017

[5] Sandra, Shristyana, and L. Sulistyorini, Hubungan Pengetahuan dan Kebiasaan Konsumen air minum isi ulang dengan penyakit diare. Surabaya: Artikel Fakultas Kesehatan Masyarakat. Universitas Airlangga, 2007.

[6] K. Theo, Pengawasan Dinas Kesehatan Pemerintah Kabupaten Banyumas Terhadap Kualitas air minum Isi Ulang (Skripsi). Fakultas Hukum Universitas Jendral Sudirman, 2013.

[7] R. Siener, A. Jahnen, and A. Hesse, "Influence of a Mineral Water Rich in Calcium, Magnesium and Bicarbonater on urine Compostion and The Risk of calcium Oxalate crystallization," Eur K.Clin.Nutr, vol. 58, pp. 270-276, 2004.

[8] H. Effendi, Telaah Kualitas Air bagi Pengelolaan Sumber daya dan Lingkungan Perairan. Yogyakarta: Kanisius, 2010.

[9] Y. Warman, "Pengawasan Kualitas Air minum Isi Ulang oleh Dinkes Kota Pekanbaru Tahun 2008," www.wordpress.com, 2008.

[10] R. Yunus and T. Yuniarti, "Gambaran Hasil Pemeriksaan Kristal Urin Orang Yang meminum Air Minum Kemasan isi Ulang (air Galon) dan orang meminum air minum dari sumur gali," Meditoty J., vol. 4, no. 1, pp. 1-6, 2016.

[11] S. Arikunto, Metode Penelitian: Prosedur Penelitian Suatu Pendekatan Praktik. Jakarta: Rineka Cipta, 2006.

[12] H. Hardjooeno and Fitriani, Substansi dan Cairan Tubuh. Makassar: Lembaga Penerbit Unhas, 2007.

[13] R. Gandasoebrata, Penuntun Laboratorium Klinik. Jakarta: Dian Rakyat, 2006.

[14] E. . Kosasih, Tafsiran Hasil Pemeriksaan Laboratorium Klinik Edisi Kedua. Jakarta: Buku Kedokteran EGC, 2008.

[15] R. Gandasoebrata, Kalsium dalam Penuntun Laboratorium Klinik. Jakarta: Dian Rakyat, 2004.

[16] A. . Sutedjo, Buku Saku Mengenal Penyakit Melalui Hasil Pemeriksaan Laboratorium. Yogyakarta: Amara Books, 2007.

[17] A. Ahmadi, "Gambaran sedimen urin pada masyarakat yang minum dari air sumur setempat di desa Jetis RT 02/III Blora," Universitas Muhammadiah Semarang, 2010.

[18] Obiet, "Perbedaan sedimen urine pada masyarakat yang mengkonsumsi air pegunangan RRI lama dan Jalan Lasolo, Kota Kendari," Bina Husada, 2014. 